\title{
Self-regulation of Pir, a Regulatory Protein Responsible for Hyperinduction of Pectate Lyase in Erwinia chrysanthemi EC16
}

\author{
Kinya Nomura, ${ }^{1}$ William Nasser, ${ }^{2}$ and Shinji Tsuyumu ${ }^{1}$ \\ ${ }^{1}$ Faculty of Agriculture, Shizuoka University, 836 Ohya, Shizuoka 422-8529 Japan; ${ }^{2}$ Centre National de la \\ Recherche Scientifique, Institut National des Sciences Appliquées, 69621 Villeurbanne, France \\ Accepted 22 January 1999.
}

\begin{abstract}
Previously, we have cloned and characterized the pir (plant inducible regulator) gene, which is responsible for hyperinduction of the synthesis of an isozyme of pectate lyase (PLe) in Erwinia chrysanthemi EC16 in the presence of potato extract and sodium polypectate (NaPP). The Pir protein purified from Escherichia coli overexpressing pir is able to bind to the promoter region of pir as a dimer. Self-regulation of pir by its own translational product (Pir) was suggested from the findings that Pir binds at the promoter region of pir and that the hyperinduction of the pirlux construct in response to plant extract was observed only in pir $^{+}$but not in pir mutant EC16. Thus, hyperinduction of PLe was thought to be mainly due to overproduction of Pir. On the other hand, KdgR and PecS, which have been reported to be the major regulatory proteins for the synthesis of pectic enzymes, did not bind to the promoter region of pir. Thus, the regulation of Pir synthesis seems to be independent of KdgR and PecS. Also, its expression was insensitive to catabolite repression as predicted from failure of cyclic AMP (cAMP)-CRP (cAMP recognizing protein) to bind at the pir promoter region.
\end{abstract}

Erwinia chrysanthemi is a phytopathogenic bacterium that causes soft-rot disease in a wide variety of host plants (Pérombelon and Kelman 1980). Its pathogenesis depends on production and secretion of depolymerizing enzymes such as pectinase, cellulase, and protease (Barras et al. 1994), and among these cell-wall-degrading enzymes, pectate lyases (PLs) that cleave sodium polypectate (NaPP) in a transeliminative manner have been considered to be the most important (Collmer and Keen 1986). Strain EC16 of E. chrysanthemi produces and secretes four major PL isozymes, named PLa, PLb, PLc, and PLe (Barras et al. 1987; Collmer and Keen 1986). These isozymes are produced from independent genes (pelA, pelB, pelC, and pelE; Brooks et al. 1990; Tamaki et al. 1988), and their expression is elevated by growth in the presence of NaPP, which is metabolized to produce the true intracellular inducer, 2-keto-3-deoxygluconate (KDG; HugovieuxCotte-Pattat and Robert-Baudouy 1987). This induction mechanism (product induction; Tsuyumu 1977) is mediated by

Corresponding author: Shinji Tsuyumu; Telephone and Fax: 81-54-2384823; E-mail: tsuyumu@ipc.shizuoka.ac.jp releasing a repressor, $\mathrm{KdgR}$, from the $\mathrm{KdgR}$-box in the promoter regions of these genes by allosteric change of $\mathrm{KdgR}$ after binding with KDG, one of the metabolic products produced from pectic substance.

Recently, we have found a new regulatory protein, Pir, that is specifically responsible for hyperinduction of pelE expression in the medium containing $\mathrm{NaPP}$ and potato extract (Nomura et al. 1998). In this paper, we show that the purified Pir protein binds at the promoter region of pir. From the analysis of induction pattern with the pir-reporter gene construct in pir $^{+}$and pir mutant backgrounds, the expression of pir was shown to be regulated by Pir (self-regulation).

\section{RESULTS}

Characterization of the pir promoter region.

The transcriptional start site for pir was determined to be at $\mathrm{G}$ located 52 nucleotides (nt) upstream from the translational start site of pir and was the same when EC16 cells were grown either in the presence or in the absence of potato extract (Figs. 1 and 2). Before this transcriptional start site, a $\sigma_{70}$ type promoter -35 region (TTGCAT, from -36 to $-31 \mathrm{nt}$ ) and -10 region (CATGAT, from -13 to $-8 \mathrm{nt}$ ) can be seen (Fig. 1). Thus, the expression of pir seems not to be dependent on a new $\sigma$ factor. The intensity of the band at the transcriptional start was highest when RNA extracted from the cells grown

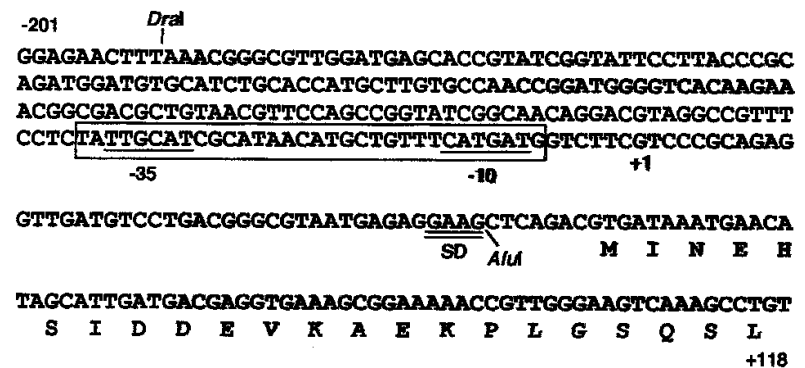

Fig. 1. Nucleotide sequence of the promoter region of the pir gene of Erwinia chrysanthemi EC16. Numbering based on transcriptional start site determined by primer extension (Fig. 2). Translational start site is at +52 nucleotides. The DraI-AluI fragment ( $235 \mathrm{bp}$ ) is used for the binding assay and construction of $l u x$ fusion. -35 and -10 regions of $\sigma_{70}$ type promoter are underlined. Boxed sequence indicates region protected by Pir from DNase I digestion. 
under hyperinducing condition (i.e., in the presence of potato extract and NaPP) was used (Fig. 2). This accumulation of Pir should lead to hyperinduction of PLe under the same conditions (Nomura et al. 1998).

DNA-binding assays on the promoter region of pir (the 267-bp XmaI-SphI fragment; Table 1) with KdgR (Nasser et al. 1991, 1992, and 1994; Reverchon et al. 1991), PecS (Praillet et al. 1996, 1997; Reverchon et al. 1994), and cyclic AMP (cAMP)-CRP (cAMP recognizing protein; Nasser et al. 1997; Reverchon et al. 1997) of E. chrysanthemi showed no

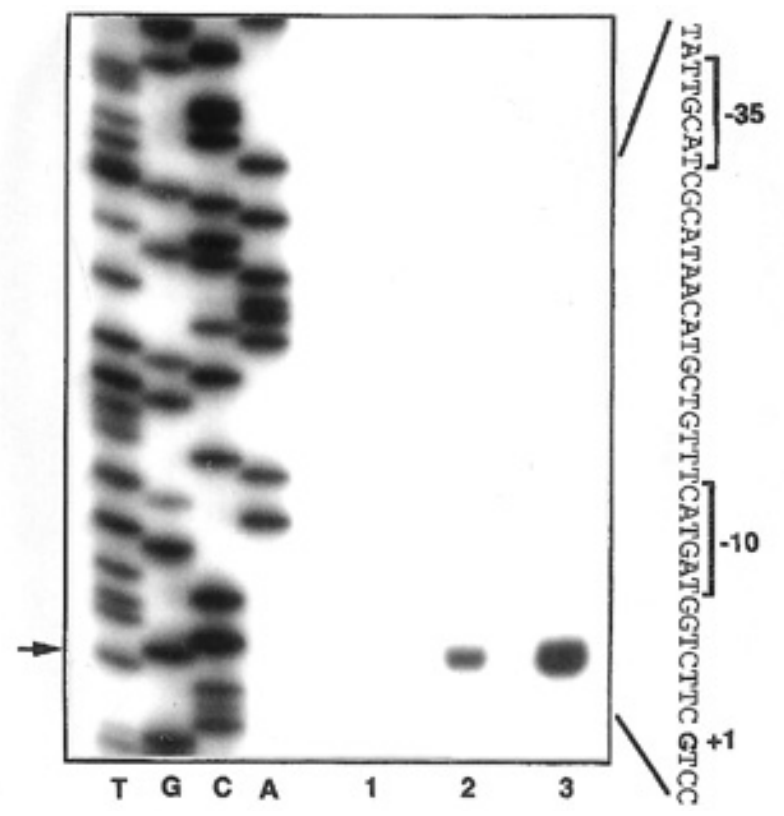

Fig. 2. Determination of transcriptional starting point of pir by primer extension analysis. Lanes A,C,G,T correspond to the DNA sequence ladders with PIRO-2 as the primer. PIRO-2 was complementary to the sequence from +117 to +97 nucleotides (nt) of the pir coding region. Results shown are after primer extension from end-labeled PIRO-2 with total RNA $(10 \mu \mathrm{g})$ preparations from EC16 cells grown in (lane 1) minimal salts + glycerol, (lane 2) minimal salts + glycerol $+\mathrm{NaPP}$, or (lane 3) minimal salts + glycerol + sodium polypectate + potato extract. shifted band (data not shown). Thus, pir expression may not be regulated by these regulatory molecules.

\section{Pir binds to the promoter region of pir.}

When the 267-bp XmaI-SphI fragment containing the pir promoter region was used as the target DNA in DNA-binding assays in the presence of purified Pir, a single retarded band was observed when Pir was added at a concentration between 30 and $120 \mathrm{nM}$ (Fig. 3). After a 100-fold molar excess of unlabeled XmaI-SphI pir fragment was added to the binding mixture, Pir-pir complex disappeared. The molecular mass of the shifted band in native PAGE (polyacrylamide gel electrophoresis) was calculated to be approximately $60 \mathrm{kDa}$ by the method of Bading (Bading 1988). The region from -38 to -7

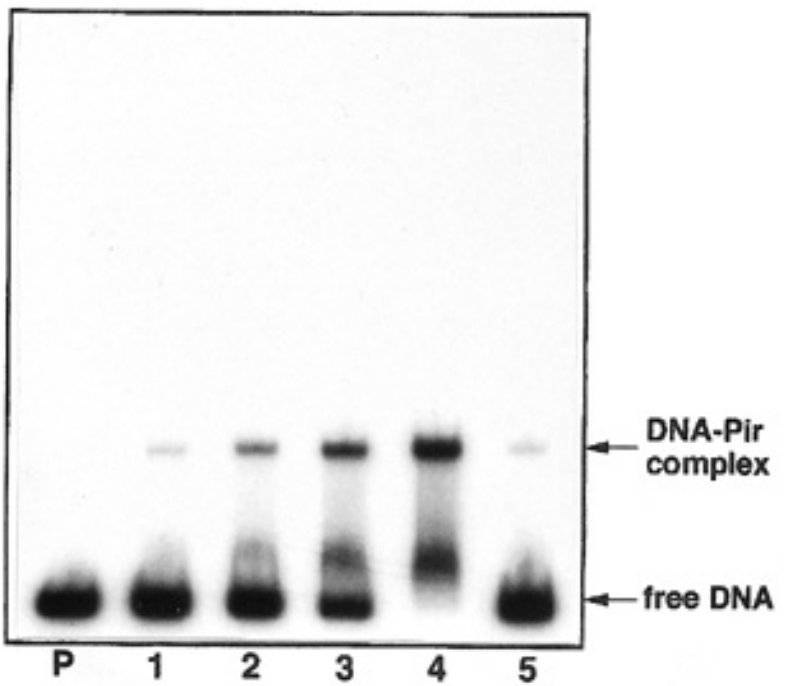

Fig. 3. DNA-binding assay on the promoter region of pir with purified Pir. The XmaI-SphI fragment of pir (267 bp) was used as probe for DNA-binding assay. Labeled XmaI-SphI fragment $(30 \mathrm{fmol})$ (free, lane P) was mixed with (lane 1) 30, (lane 2) 50, (lane 3) 70, or (lane 4) 120 $\mathrm{nM}$ concentrations of purified Pir. Lane 5, same condition as lane 4, except that it contains a 100-fold molar excess of unlabeled XmaI-SphI fragment of pir.

Table 1. Bacterial strains and plasmids

\begin{tabular}{|c|c|c|}
\hline Strain or plasmid & Description & Source or reference \\
\hline \multicolumn{3}{|l|}{ Strain } \\
\hline \multicolumn{3}{|l|}{ Escherichia coli } \\
\hline MV1184 & 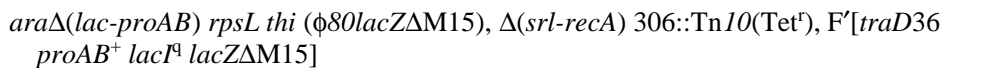 & Nippon Gene, Tokyo \\
\hline BL21 (DE3) & $\mathrm{F}^{\prime}$ ompT hsdSB $\left(\mathrm{rB}^{-} \mathrm{mB}^{-}\right)$gal dcm (DE3) & Novagen, Madison, WI \\
\hline \multicolumn{3}{|c|}{ Erwinia chrysanthemi } \\
\hline EC16 & Wild type & A. Chatterjee, University of Mi ssouri \\
\hline K2367 & gus-km cassette insertion mutant of pir, $\mathrm{Pir}^{-}, \mathrm{Km}^{\mathrm{r}}$ & Nomura et al. 1998 \\
\hline EPIR16 & EC16 integrants of Tn 7-lux pir promoter construct, $\mathrm{St}^{\mathrm{r}}$ & This study \\
\hline KPIR2367 & K2367 integrants of Tn 7-lux pir promoter construct, $\mathrm{Pir}^{-}, \mathrm{St}^{\mathrm{r}}, \mathrm{Km}^{\mathrm{r}}$ & This study \\
\hline \multicolumn{3}{|c|}{ 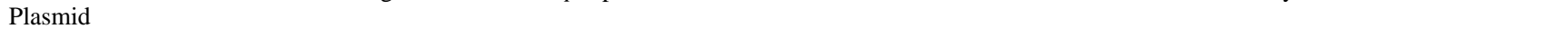 } \\
\hline pUC118 & Cloning vector, $\mathrm{Ap}^{\mathrm{r}}$ & Nippon Gene \\
\hline pHSK728 & Tn7-lux transcriptional fusion vector, $\mathrm{Ap}^{\mathrm{r}}, \mathrm{St}^{\mathrm{r}}$ & Shen et al. 1992 \\
\hline pMON7181 & Helper plasmid carrying genes for $\mathrm{Tn} 7$ transposition, $\mathrm{Gm}^{\mathrm{r}}$ & Barry 1988 \\
\hline pET21a-d(+) & $\mathrm{T} 7$ overexpression vector, $\mathrm{Ap}^{\mathrm{r}}$ & Novagen \\
\hline pIEC-1 & $\begin{array}{l}\text { 1.45-kbp EcoRV-KpnI fragment containing pir cloned into the SmaI-KpnI site of } \\
\text { pUC118 }\end{array}$ & Nomura et al. 1998 \\
\hline pPIR-PR & 235-bp DraI-AluI fragment from pIEC-1 cloned into the SmaI site of pUC118 & This study \\
\hline pPIR-LUX & 235-bp DraI-AluI fragment from pIEC-1 cloned into the SmaI site of pHSK728 & This study \\
\hline pET-PIR & $\begin{array}{l}\text { 1.1-kbp NdeI-EcoRI fragment containing pir open reading frame cloned into the NdeI- } \\
\text { EcoRI site of pET21a-d(+) }\end{array}$ & This study \\
\hline
\end{tabular}


nt in the pir promoter was shown to be protected by Pir from digestion with DNase I in a footprinting experiment (Fig. 4). This sequence (ATAACATGCTGTTTCAT, from -27 to $-11 \mathrm{nt}$ ) was similar to the sequence (ACAAAATGGCATTTCAT) in the promoter region of pelE protected from the digestion (Nomura et al. 1998). These results indicated that Pir specifically binds to the region from -38 to $-7 \mathrm{nt}$ in the pir promoter as a dimer.

\section{Self-regulation of pir.}

Expression of the pir-lux construct in EC16 increased in the presence of either NaPP or potato extract, compared with that in minimal salts + glycerol, but it increased further in the presence of both NaPP and potato extract (Fig. 5). In K2367 (pir mutant), however, induction and hyperinduction observed in EC16 were significantly reduced. Since Northern (RNA) blot experiments with a pir clone as the probe showed that the transcription of pir is monocistronic (data not shown), the pir phenotype was thought to reflect the loss of only pir. Pir binds to its pir promoter region (Figs. 3 and 4) and pir expression is reduced in the pir mutant. These results suggest that the expression of pir was self-regulated in a positive manner by its own translational product only in the presence of potato extract.

In the medium containing NaPP alone, pir expression in EC16 and in K2367 was approximately the same. Thus, the induction of the synthesis of Pir in this condition seems to be controlled by a regulatory protein other than Pir. Failure of binding of $\mathrm{KdgR}$ and $\mathrm{PecS}$ to the pir promoter indicates that this regulatory protein should be other than $\mathrm{KdgR}$ and PecS. Also, since pir-lux expression was high even in the presence of glucose (data not shown), the expression of pir is insensitive to catabolite repression. This result is consistent with the absence of binding of CRP at the pir promoter region.

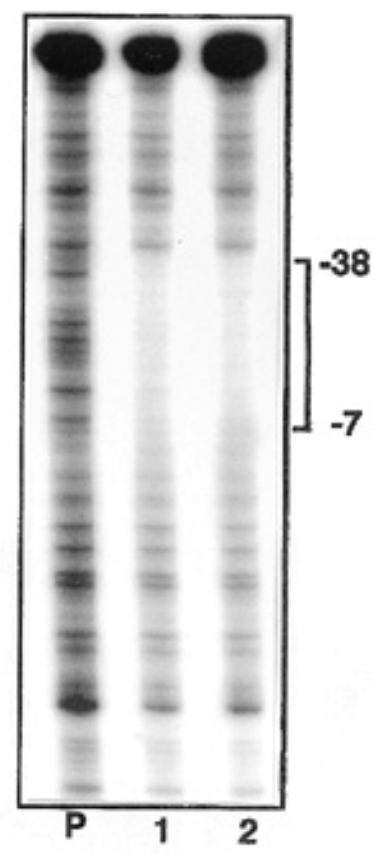

Fig. 4. Determination of binding site for Pir on the promoter region of pir. DNase I footprinting was performed after binding with purified Pir protein. Labeled XmaI-SphI fragment (30 fmol) (free, lane P) was mixed with (lane 1) 80 or (lane 2) $120 \mathrm{nM}$ concentrations of purified Pir.

\section{Plant sources for hyperinduction of Pir.}

In EC16, hyperinduction of pir was observed when cells were grown in the presence of extracts of not only potato but also celery, Chinese cabbage, and carrot, and hyperinduction was not observed in K2367 (Table 2). Thus, the potential inducing factor(s) for hyperinduction of pir that lead to the hyperinduction of PL synthesis may be widely distributed in the plant.

\section{A EPIR16 (wild-type)}

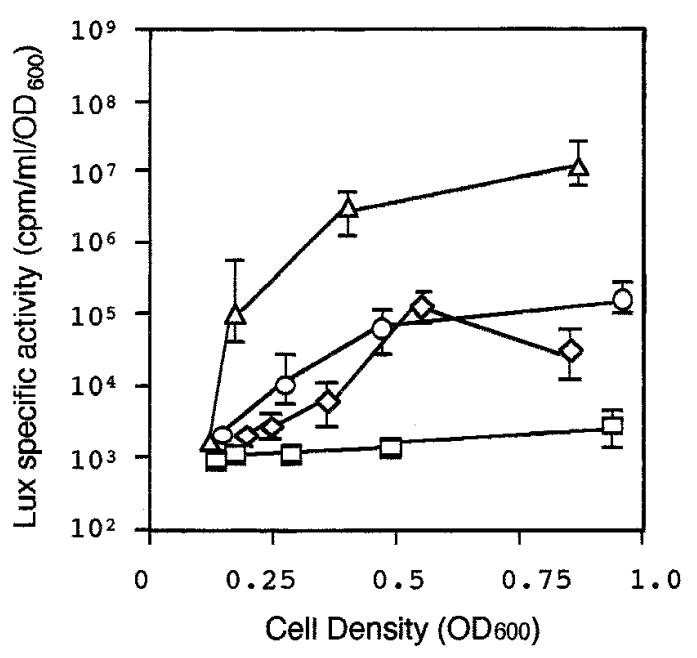

\section{B KPIR2367 (pir)}

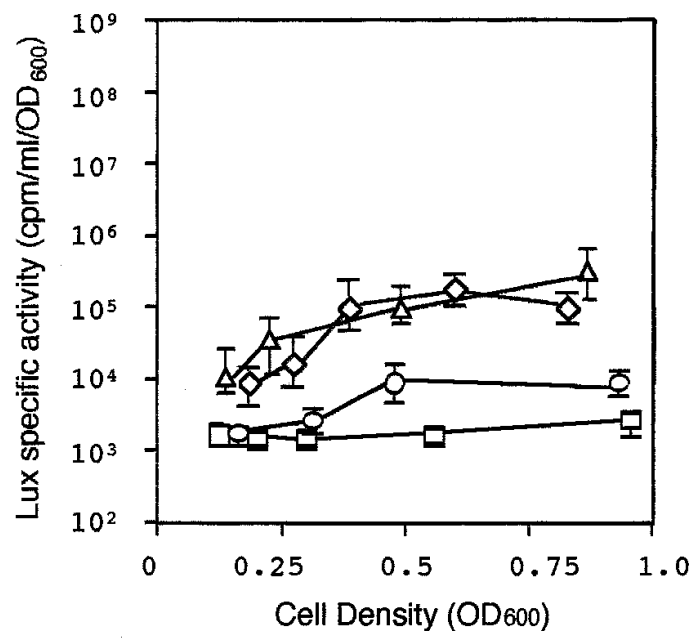

Fig. 5. Positive autoregulation of pir. Light production by EC16 (A, EPIR16) and pir deficient mutant K2367 (B, KPIR2367) carrying the pir-lux construct were measured with a chemiluminescence detector. Specific activity of pir-lux was expressed as cpm per ml per cell density $\left(\mathrm{cpm} / \mathrm{ml} / \mathrm{OD}_{600}\right)$. Background value of this detector was about $10^{3}$ $\mathrm{cpm} / \mathrm{ml} / \mathrm{OD}_{600}$. Symbols: open square, minimal salts + glycerol; open diamond, minimal salts + glycerol + sodium polypectate $(\mathrm{NaPP})$; open circle, minimal salts + glycerol + potato extract; open triangle, minimal salts + glycerol $+\mathrm{NaPP}+$ potato extract. Carbon sources were added to the minimal salts at the following concentrations: glycerol, 2 g/liter; NaPP, 2 g/liter; potato extract, $1 \%$. All cultures were grown on a shaker at $27^{\circ} \mathrm{C}$. Each value is the average of at least five determinations. 


\section{DISCUSSION}

A single start site for the transcription of pir was found at $52 \mathrm{nt}$ upstream from the translational start site, when EC16 cells were grown either in the presence or in the absence of potato extract (Fig. 1). Before this transcriptional start site, a typical $\sigma_{70}$ type promoter was observed. Thus, unlike the case with the hrp operon (Fenselau and Bonas 1995; Wengelnik and Bonas 1996), the induction of pir expression seems to require no new $\sigma$ factor in responding to the plant extract. From the hyperinducible nature of Pir synthesis in the medium containing plant extract in addition to NaPP and glycerol, known regulatory proteins for enzymes such as $\mathrm{KdgR}$ and $\mathrm{PecS}$ were thought to be involved in its regulation. However, since none of these molecules bound to the promoter region of pir (data not shown), they seem not to be involved in regulation of Pir synthesis. Also, though many genes including pel have been reported to be regulated by catabolite repression with the cAMPCRP complex as a positive factor (Nasser et al. 1997; Reverchon et al. 1997; Tsuyumu 1979), cAMP-CRP did not bind to the regulatory region of pir and the expression of pir was insensitive to catabolite repression (data not shown). Thus, the regulation of pir expression is distinguishable from the control of expression of the genes encoding pectin catabolizing enzymes.

Addition of extracts of different plants such as celery, Chinese cabbage, or carrot together with NaPP could also enhance the expression of pir (Table 2), which led to hyperinduction of pectin catabolizing enzymes production. In the $E$. chrysanthemi strain 3937, partial purification of the plant component that hyperinduces the production of PL has been reported (Bourson et al. 1993). This plant component is thermoresistant, of low molecular mass, and very hydrophilic. The plant component responsible for hyperinduction of Pir synthesis in our study was also thermoresistant and hydrophilic (data not shown). Thus, the hyperinducing factor in plants for pir expression may be similar in chemical nature.

DNase I footprinting analysis showed that Pir protects -38 to $-7 \mathrm{nt}$ in the pir promoter region from DNase I digestion (Figs. 1 and 4). The Pir binding site in the promoter region of pir overlapped with the RNA polymerase binding site ( -48 to +5 nt; Collado-Vides et al. 1991). Thus, binding of Pir to the

Table 2. Expression of the pir gene in various environmental conditions ${ }^{\mathrm{a}}$

\begin{tabular}{lcc}
\hline & \multicolumn{2}{c}{$\begin{array}{c}\text { Lux-specific activity } \\
\left(\mathbf{1 0} \mathbf{c p m}^{\mathbf{4}} \mathbf{\text { ml/OD }} \mathbf{6 0 0}\right.\end{array}$} \\
\cline { 2 - 3 } Carbon source & $\begin{array}{c}\text { EPIR16 } \\
\text { (wild-type) }\end{array}$ & $\begin{array}{c}\text { KPIR } \\
\text { (pir } \text { mutant) }\end{array}$ \\
\hline Glycerol + sodium polypectate $(\mathrm{NaPP})$ & $5.7 \pm 2.9$ & $12.1 \pm 11.9$ \\
Glycerol + NaPP + potato extract & $596.3 \pm 398.4$ & $15.6 \pm 10.6$ \\
Glycerol + NaPP + celery extract & $315.5 \pm 130.5$ & $52.3 \pm 49.0$ \\
Glycerol + NaPP + carrot extract & $384.6 \pm 110.8$ & $75.7 \pm 28.6$ \\
Glycerol + NaPP + Chinese cabbage & $669.2 \pm 353.9$ & $19.8 \pm 13.5$ \\
$\quad$ extract & & \\
\hline
\end{tabular}

${ }^{a}$ Light production by EC16 (EPIR16) and pir-deficient mutant K2367 (KPIR2367) carrying the pir-lux construct was measured by a chemiluminescence detector. All cultures were grown on a shaker at $27^{\circ} \mathrm{C}$ until optical density at $600 \mathrm{~nm}$ of the culture reached at 0.8 .

b Specific activity of pir-lux was expressed as cpm per ml per cell density $\left(\mathrm{cpm} / \mathrm{ml} / \mathrm{OD}_{600}\right)$. Background value of this detector was about $10^{3}$ $\mathrm{cpm} / \mathrm{ml} / \mathrm{OD}_{600}$. Each value is average of at least three determinations.

${ }^{c}$ Plant extracts (final concentration at $1 \%$ ) were added into the minimal medium containing glycerol ( 2 g/liter) and NaPP (2 g/liter). pir promoter was thought to interact with RNA polymerase. Since Pir production was elevated in the presence of plant extract only in the wild type but not in the pir mutant (Fig. 5), Pir was thought to act positively on the transcription of pir rather than competitively. Pir may also act as an antirepressor, as previously suggested in the case of pelE regulation (Nomura et al. 1998). Thus, a high concentration of Pir in the cell inhibits the binding of an unidentified, specific pir repressor, which results in enhancement of pir gene expression. Future studies of this system will focus on understanding the precise mechanism (direct or indirect) by which Pir activates its own gene expression as well as expression of the pel genes.

\section{MATERIALS AND METHODS}

\section{Bacterial strains and growth media.}

The bacterial strains and plasmids used in this study are listed in Table 1. Strains of E. chrysanthemi and of Escherichia coli were grown at $27^{\circ} \mathrm{C}$ in $\mathrm{YP}$ medium $(1 \%$ polypeptone, $0.5 \%$ yeast extract, $\mathrm{pH} 6.8$ ) and at $37^{\circ} \mathrm{C}$ in $\mathrm{LB}$ (Luria-Bertani) medium ( $1 \%$ polypeptone, $0.5 \%$ yeast extract, $1 \% \mathrm{NaCl}, \mathrm{pH} 7.0$ ), respectively. M63 medium (Miller 1972) supplemented with a carbon source $(0.2 \%)$ was used as minimal medium for both bacterial genera. Antibiotics were added at the following concentrations; ampicillin (Ap, $100 \mu \mathrm{g} / \mathrm{ml})$, kanamycin $(\mathrm{Km}, 150 \mu \mathrm{g} / \mathrm{ml})$, streptomycin (St, $25 \mu \mathrm{g} / \mathrm{ml})$, and gentamycin $(\mathrm{Gm}, 15 \mu \mathrm{g} / \mathrm{ml})$. A crude plant extract was prepared by centrifugation at $10,000 \times g$ for $10 \mathrm{~min}$ of homogenized extracts of plant tissues by grater followed by filtration through $0.45-\mu \mathrm{m}$ nitrocellulose filters (Kurabo, Osaka, Japan). One hundredth volume of this extract was added to minimal medium.

\section{Primer extension analysis.}

Primer extension analysis was performed as described by Ausubel et al. (1987). The oligonucleotide PIRO-2 (5'dCAGGCTTTGACTTCCCAACGG-3'), which was complementary to the sequence from +117 to $+97 \mathrm{nt}$ in the pir coding region (Fig. 1), was used as the primer. PIRO-2 was end-labeled with $\mathrm{T} 4$ polynucleotide kinase with $100 \mu \mathrm{Ci}$ of $\left[\gamma^{32} \mathrm{P}\right]$ ATP $(3,000 \mathrm{Ci} / \mathrm{mmol})$. Total RNA was isolated with the ISOGEN RNA isolation kit (Wako, Osaka, Japan) from cells grown to late log phase. Ten micrograms of total RNA was annealed with $1 \times 10^{6} \mathrm{cpm}$ of the labeled PIRO-2 at $65^{\circ} \mathrm{C}$ for 2 $\mathrm{h}$ in hybridization buffer $(10 \mathrm{mM}$ Tris- $\mathrm{HCl} \mathrm{pH} 8.3,1 \mathrm{mM}$ EDTA $\mathrm{pH} 8.0,150 \mathrm{mM} \mathrm{KCl})$. Extension reaction was performed with avian myeloblastosis virus reverse transcriptase (Wako, Osaka, Japan) in the reaction mixture $(50 \mathrm{mM}$ Tris$\mathrm{HCl} \mathrm{pH} 8.3,25 \mathrm{mM} \mathrm{MgCl} 2,50 \mathrm{mM} \mathrm{KCl}, 3 \mu \mathrm{g}$ of actinomycin D per ml, $0.2 \mathrm{mM}$ dNTP mix, $5 \mathrm{mM}$ DTT [dithiothreitol]) at $45^{\circ} \mathrm{C}$ for $1 \mathrm{~h}$. Reaction was stopped by adding $3 \times$ volume $(150$ $\mu \mathrm{l})$ of stop solution $(100 \mu \mathrm{g}$ of salmon sperm DNA per $\mathrm{ml}, 20$ $\mu \mathrm{g}$ of RNase A per $\mathrm{ml}$ ). Extended fragments were ethanol precipitated after phenol/chloroform extraction, resuspended in 3 $\mu \mathrm{l}$ of dye mixture, and loaded onto a $6 \%$ polyacrylamide-urea sequencing gel. Manual DNA sequencing was done with the T7 polymerase sequencing kit (Pharmacia Biotech, Uppsala, Sweden) with a clone containing the pir gene (pIEC-1; Table 1) as the template DNA and PIRO-2 as the primer, and run in the lanes next to those for primer extension. After electrophoresis, the gel was vacuum dried and exposed to HP film (Amersham, Buckinghamshire, UK). 
Purification of Pir protein after overexpression.

With the two oligonucleotides PIRO-3 (5'-AGCTCACAT ATGATAAATGAACATAGC-3') and PUC-3 (5'-GGAAACA GCTATGACCATG-3') as the primers, a 1.1-kbp DNA fragment containing the pir open reading frame with an NdeI site at the $5^{\prime}$ end and an EcoRI site at the $3^{\prime}$ end was obtained after polymerase chain reaction (PCR) with pIEC-1 as the template DNA (Table 1). After amplification, an NdeI-EcoRI fragment was cloned into the corresponding sites of $\mathrm{T} 7$ overexpression vector pET21a-d(+) (Novagen, Madison, WI). After confirmation of absence of mutation, this construct (pET-PIR) was introduced into E. coli BL21 (DE3) by electroporation (18.4 $\mathrm{kV} / \mathrm{cm}, 300 \mu \mathrm{F}$, and $4 \mathrm{ohms}$ ). Pir was purified from $100 \mathrm{ml}$ of E. coli BL21 (DE3) cells grown in LB broth with $150 \mu \mathrm{g}$ of Ap per ml. When the optical density at $600 \mathrm{~nm}$ of the culture reached 0.8, 0.6 mM IPTG (isopropyl-D-thiogalactopyranoside) was added to the culture to induce the expression of pir for $2 \mathrm{~h}$. The Pir protein was purified after ammoniumsulfate precipitation (25 to $40 \%$ ) and HEPARIN POROS column (Roche Diagnostics, Mannheim, Germany) chromatography. Conditions of these purification steps were previously described (Nomura et al. 1998). The concentration of purified Pir was determined by the Bradford kit (Bio-Rad, Hercules, $\mathrm{CA})$ and was stored in a frozen state $\left(-20^{\circ} \mathrm{C}\right)$ in buffer A (Nomura et al. 1998) with 50\% glycerol. The yield of this two-step purification procedure was approximately $1 \mathrm{mg}$ from $100 \mathrm{ml}$ of culture.

DNA-binding assay and DNase I footprinting.

DNA-binding assays and DNase I footprinting were performed as described previously (Nomura et al. 1998).

\section{Recombinant DNA techniques.}

Preparation of plasmid DNA, restriction digestion, ligation, and DNA electrophoresis were done as described by Sambrook et al. (1989). Restriction and modifying enzymes were obtained from Nippon Gene (Toyama, Japan) and New England Biolabs (Beverly, MA).

\section{Insertion of pir promoter-lux fusion into a chromosome of $E$. chrysanthemi.}

A 235-bp DraI-AluI fragment containing the pir promoter region (-192 to $+43 \mathrm{nt}$; Fig. 1) was ligated into the SmaI site of pHSK728 (Shen et al. 1992) to construct the pir-lux fusion. The pir-lux construct was inserted into the single attachment site on the chromosome of EC16 and pir-deficient mutant K2367 by the Tn7 transposition system (Barry 1988; Gold et al. 1992; Nomura et al. 1998).

\section{Bioluminescence assay.}

Light production in $10 \mathrm{~s}$ by EC16 containing the pir-lux construct on its chromosome was measured 3 times every hour by the chemiluminescence detector CLD-100 (Tohoku Electronic, Sendai, Japan). The mean of 3 readings (cpm) in 1 $\mathrm{ml}$ was divided by optical density at $600 \mathrm{~nm}$ and used as the specific luciferase activity $\left(\mathrm{cpm} / \mathrm{ml} / \mathrm{OD}_{600}\right)$.

\section{ACKNOWLEDGMENTS}

We are extremely grateful to Guy Condemine, Nicole HugouvieuxCotte-Pattat, and Sylvie Reverchon for reading carefully the manuscript.
This research was supported in part by a scientific promotion grant from the Ministry of Education, Japan (no. 09460026), and by a grant in Plant Biotechnology from the Ministry of Agriculture, Forestry and Fisheries of Japan.

\section{LITERATURE CITED}

Ausubel, F. M., Brent, R., Kingston, R. E., Moore, D. D., Seidman, J. G., Smith, J. A., and Struhi, K. 1987. Current Protocols in Molecular Biology. Wiley Interscience, New York.

Bading, H. 1988. Determination of the molecular mass of DNA bound protein(s) responsible for gel electrophoresis mobility shift of linear DNA fragments exemplified with purified viral myb protein. Nucleic Acids Res. 16:5241-5248.

Barras, F., Gijsegem, F. V., and Chatterjee, A. K. 1994. Extracellular enzymes and pathogenesis of soft-rot Erwinia. Annu. Rev. Phytopathol. 32:201-234.

Barras, F., Thurn, K. K., and Chatterjee, A. K. 1987. Resolution of four pectate lyase structural genes of Erwinia chrysanthemi (EC16) and characterization of the enzymes produced in Escherichia coli. Mol. Gen. Genet. 209:319-325.

Barry, G. F. 1988. A broad-host-range shuttle system for gene insertion into the chromosomes of Gram-negative bacteria. Gene 71:75-84.

Bourson, C., Favey, S., Reverchon, S., and Robert-Baudouy, J. 1993. Regulation of the expression of a pelA::uidA fusion in Erwinia chrysanthemi and demonstration of the synergistic action of plant extract with polygalacturonate on pectate lyase synthesis. J. Gen. Microbiol. 139:1-9.

Brooks, A. D., He, S. Y., Gold, S., Keen, N. T., Collmer, A., and Hutcheson, S. W. 1990. Molecular cloning of the structural gene for exopolygalacturonate lyase from Erwinia chrysanthemi EC16 and characterization of the enzyme product. J. Bacteriol. 172:69506958.

Collado-Vides, J., Magasanik, B., and Gralla, J. D. 1991. Control site location and transcriptional regulation in Escherichia coli. Microbiol. Rev. 371-394.

Collmer, A., and Keen, N. T. 1986. The role of pectic enzymes in plant pathogenesis. Annu. Rev. Phytopathol. 24:383-409.

Fenselau, S., and Bonas, U. 1995. Sequence and expression analysis of the $h r p B$ pathogenicity operon of Xanthomonas campestris pv. vesicatoria which encodes eight proteins with similarity to components of the Hrp, Ysc, Spa, and Fli secretion systems. Mol. Plant-Microbe Interact. 8:845-854.

Gold, S., Nishio, S., Tsuyumu, S., and Keen, N. T. 1992. Analysis of the pelE promoter in Erwinia chrysanthemi EC16. Mol. Plant-Microbe Interact. 5:170-178.

Hugouvieux-Cotte-Pattat, N., and Robert-Baudouy, J. 1987. Hexuronate catabolism in Erwinia chrysanthemi. J. Bacteriol. 169:1223-1231.

Miller, J. H. 1972. Experiments in Molecular Genetics. Cold Spring Harbor Laboratory, Cold Spring Harbor, NY.

Nasser, W., Condemine G., Plantier, R., Anker, D., and Robert-Baudouy, J. 1991. Inducing properties of analogs of 2-keto-3-deoxygluconate on the expression of pectate lyase genes of Erwinia chrysanthemi. FEMS Microbiol. Lett. 81:73-78.

Nasser, W., Reverchon, S., Condemine, G., and Robert-Baudouy, J. 1994. Specific interactions of Erwinia chrysanthemi $\mathrm{KdgR}$ repressor with different operators of genes involved in pectinolysis. J. Mol. Biol. 236:427-440.

Nasser, W., Reverchon, S., and Robert-Baudouy, J. 1992. Purification and functional characterization of the KdgR protein, a major repressor of pectinolysis genes of Erwinia chrysanthemi. Mol. Microbiol. 6: 257-265.

Nasser, W., Robert-Baudouy, J., and Reverchon, S. 1997. Antagonistic effect of CRP and KdgR in the transcription control of the Erwinia chrysanthemi pectinolysis genes. Mol. Microbiol. 26:1071-1082.

Nomura, K., Nasser, W., Kawagishi, H., and Tsuyumu, S. 1998. The pir gene of Erwinia chrysanthemi EC16 regulates hyperinduction of pectate lyase virulence gene in response to plant signals. Proc. Natl. Acad. Sci. USA 95:14034-14039.

Pérombelon, M. C. M., and Kelman, A. 1980. Ecology of the soft rot erwinias. Annu. Rev. Phytopathol. 18:361-387.

Praillet, T., Nasser, W., Robert-Baudouy, J., and Reverchon, S. 1996. Purification and functional characterization of PecS, a regulator of 
virulence-factor synthesis in Erwinia chrysanthemi. Mol. Microbiol. 20:391-402.

Praillet, T., Reverchon, S., Robert-Baudouy, J., and Nasser, W. 1997. The PecM protein is necessary for the DNA-binding capacity of the $\mathrm{PecS}$ repressor, one of the regulators of virulence-factor synthesis in Erwinia chrysanthemi. FEMS Microbiol. Lett. 154:265-270.

Reverchon, S., Expert, D., Robert-Baudouy, J., and Nasser, W. 1997. The cyclic AMP receptor protein is the main activator of pectinolysis genes in Erwinia chrysanthemi. J. Bacteriol. 179:3500-3508.

Reverchon, S., Nasser, W., and Robert-Baudouy, J. 1991. Characterization of KdgR, a gene of Erwinia chrysanthemi that regulates pectin degradation. Mol. Microbiol. 5:2203-2216.

Reverchon, S., Nasser, W., and Robert-Baudouy, J. 1994. pecS: A locus controlling pectinase, cellulase and blue pigment production in $\mathrm{Er}$ winia chrysanthemi. Mol. Microbiol. 11:1127-1139.

Sambrook, J., Fritsch, E. F., and Maniatis, T. A. 1989. Molecular Clon- ing: A Laboratory Manual. 2nd ed. Cold Spring Harbor Laboratory, Cold Spring Harbor, NY.

Shen, H., Gold, S. E., Tamaki, S. J., and Keen, N. T. 1992. Construction of a Tn7-lux system for gene expression studies in gram-negative bacteria. Gene 122:27-34.

Tamaki, S. J., Gold, S., Robeson, M., Manulis, S., and Keen, N. T. 1988. Structure and organization of the pel genes of Erwinia chrysanthemi EC16. J. Bacteriol. 170:3468-3478.

Tsuyumu, S. 1977. Inducer of pectic acid lyase in Erwinia carotovora. Nature 269:237-238.

Tsuyumu, S. 1979. "Self-catabolite repression" of pectate lyase in $\mathrm{Er}$ winia carotovora. J. Bacteriol. 137:1035-1036.

Wengelnik, K., and Bonas, U. 1996. HrpXv, an AraC-type regulator, activates expression of five of the six loci in the hrp cluster of Xanthomonas campestris pv. vesicatoria. J. Bacteriol. 178:34623469. 